\title{
IDENTIFIKASI BATUAN GUNUNG API PURBA DI PEGUNUNGAN SELATAN YOGYAKARTA BAGIAN BARAT BERDASARKAN PENGUKURAN GEOLISTRIK
}

\section{ANCIENT VOLCANIC ROCKS IDENTIFICATION THE WESTERN PART OF YOGYAKARTA SOUTHERN MOUNTAINS BASED ON GEOELECTRICAL MEASUREMENT}

\author{
Winarti* dan Hill Gendoet Hartono \\ Jurusan Teknik Geologi Sekolah Tinggi Teknologi Nasional Yogyakarta \\ Jl. Babarsari, Catur Tunggal, Depok Sleman, Yogyakarta, 55281 \\ *E-mail: winyayadina@yahoo.com
}

Naskah diterima: 15 November 2014, direvisi: 18 Maret 2015, disetujui: 11 Mei 2015

\begin{abstract}
ABSTRAK
Daerah penelitian berada di perbatasan antara Dataran Yogyakarta dengan Pegunungan Selatan Yogyakarta bagian barat. Secara morfologi dan litologi yang tersingkap, indikasi gunung api purba yang dibuktikan dengan keterdapatan batuan gunung api seperti lava, breksi, dan tuf. Tujuan dari penelitian ini adalah identifikasi adanya batuan gunung api purba di bawah permuaan sepanjang Berbah-Imogiri berdasarkan data geolistrik. Metode yang digunakan adalah melakukan pengukuran geolistrik di empat lokasi secara mapping dengan konfigurasi dipole-dipole. Panjang bentangan untuk setiap lintasan 500 meter. Hasil pengukuran geolistrik menunjukkan pada lintasan 1 di Sumber KulonKalitirto, Kecamatan Berbah,diinterpretasi adanya batuan gunung api berupa lava basal dan tuf. Lintasan 2 di Pilang-Srimulyo, Kecamatan Piyungan, diinterpretasi berupa breksi skoria. Lintasan 3 di Ngeblak-Bawuran, Kecamatan Pleret, diinterpretasi adanya tuf dan lava. Lintasan 4 di Guyangan-Wonolelo, Kecamatan Pleret diinterpretasi berupa tuf dan lava. Batuan gunung api secara umum terbaca mempunyai nilai tahanan jenis yang tinggi, yaitu $>300 \Omega \mathrm{m}$. Adanya kandungan air atau mineralisasi cenderung menurunkan nilai tahan jenis batuan gunung api tersebut.
\end{abstract}

Kata kunci: batuan gunung api, geolistrik, tahanan jenis

\section{ABSTRACT}

The study area is located between western part of Yogyakarta plains and Southern Mountains. The morphology and lithology along the Berbah-Imogiri show the existence of an ancient volcano. This is proven by outcrop of volcanic rock like lava, breccia and tuff. The aim of this study is to identify the existence of ancient volcanic rocks along Berbah-Imogiri based on geoelectrical data. The method used to perform measurements at four locations geoelectrical mapping with dipole-dipole configuration a long stretch of track for every 500 meters. Geoelectrical measurement results showed on track 1 in Source Kulon-Kalitirto, District Berbah, interpreted as volcanic rocks such as basalt lava and tuff. Tracks 2 in Pilang- 
Srimulyo, District Piyungan, iterpreted as volcanic rocks of scoria breccia. Tracks 3 in Ngeblak-Bawuran, District Pleret, interpreted as lava and tuff. And track 4 on GuyanganWonolelo, District Pleret interpreted as form of tuff and lava. Volcanic rocks are generally having a high resistivity value $>300 \Omega \mathrm{m}$. The content of water or mineralization tends to reduce the resistivity value of resistant volcanic rock.

Keywords: volcanic rock, geoelectric, resistivity

\section{PENDAHULUAN}

Secara umum tektonika di selatan Pulau Jawa dipengaruhi oleh zona subduksi dari lempeng Samudra Hindia-Australia di bawah kerak benua Eropa-Asia yang terjadi sejak pertengahan Zaman Tersier. Akibat pergerakan subduksi tersebut menghasilkan gejala magmatisme-volkanisme. Hal ini dibuktikan dengan adanya batuan gunung api berumur Tersier (gunung api purba) yang diperkuat dengan munculnya lava dan breksi gunung api di beberapa tempat di Yogyakarta. Gunung api purba tersebut tercermin sebagai bukit-bukit terisolir, yang membentang dari Berbah-Imogiri. Lokasi tersebut merupakan perbatasan antara rangkaian Pegunungan Selatan Yogyakarta bagian barat dengan Dataran Yogyakarta ${ }^{[1]}$.

Keberadaan gunung api purba di lokasi tersebut memang tidak mudah dilihat di permukaan karena bentuk bentang alamnya sudah lapuk dan tererosi lanjut sehingga penampakan visual bentuk tubuh dan proses volkanisme seperti gunung api masa kini tidak bisa terlihat. Oleh karena itu, untuk identifikasi keterdapatan gunung api purba perlu dilakukan survei geologi bawah permukaan, dalam hal ini geolistrik. . Daerah ini telah dilakuakn penelitian berdasarkan data permukaan untuk mengindikasikan adanya gunung api purba di sepanjang Berbah-Imogiri $^{[2]}$. Akan tetapi, penelitian yang mengkaitkan antara data permukaan dengan data bawah permukaan belum pernah dilakukan.

Tujuan dari penelitian adalah mengidentifikasi adanya batuan gunung api di Pegunungan Selatan Yogyakarta bagian barat khususnya di sepanjang jalur Berbah-Imogiri, dengan mendasarkan kisaran harga tahanan jenis batuan. Nantinya diharapkan akan teridentifikasi keberadaan gunung api masa lampau jika terbukti batuan gunung api tersebut ada.

Lokasi penelitian berada di empat wilayah (Gambar 1), yaitu di Dusun Sumber Kulon Desa-Kalitirto Kecamatan Berbah Kabupaten Sleman, Dusun Pilang DesaSrimulyo Kecamatan Piyungan Kabupaten Bantul, Dusun Ngeblak-DesaBawuran Kecamatan Pleret Kabupaten Bantul dan Dusun Guyangan-Desa Wonolelo, Kecamatan Pleret, Kabupaten Bantul (Gambar 1).

\section{DASAR TEORI \\ Geolistrik Resistivitas}

Metode resistivitas merupakan salah satu metode geofisika yang dapat memberikan gambaran susunan litologi atau struktur bawah permukaan suatu daerah berdasarkan sifat kelistrikan batuan ${ }^{[3]}$. Batuan merupakan medium yang dapat menghantarkan arus listrik karena di dalam batuan terdapat elektron dan ion-ion yang menjalar di dalam struktur batuan dan air tanah jika di dalam batuan diberikan beda potensial. Resistivitas batuan dapat dihitung dengan mengetahui 
besar arus yang dipancarkan melalui elektroda tersebut dan besar potensial yang dihasilkan.

Prinsip dasar metode geolistrik tahanan jenis adalah Hukum Ohm dimana hambatan diperoleh dengan mengukur beda potensial dan arus yang dilewatkan dalam suatu penghantar. Arus yang mengalir (I) pada suatu medium sebanding dengan potensial (V) yang terukur dan berbanding terbalik dengan resistansi (R) medium, atau dapat dirumuskan sebagai berikut:

$$
R=\frac{V}{I}
$$

Konsep dasar pengukuran resistivitas batuan dimodifikasikan dari pengukuran tahanan suatu sampel bahan di laboratorium yang skemanya diberikan oleh Gambar $2^{[4]}$.

$$
R=\rho \frac{L}{A}
$$

dengan $\mathrm{R}=$ tahanan yang diukur $(\Omega), \rho=$ resistivitas bahan $(\Omega \mathrm{m}), \mathrm{L}=$ panjang (meter) dan $A=$ luas penampang (meter). Dengan menggabungkan persamaan (1) dan persamaan (2) maka diperoleh:

$$
\rho=\frac{V}{I} \cdot \frac{A}{L} .
$$

Besarnya kisaran harga tahanan jenis dari beberapa jenis batuan dan mineral terlihat pada Tabel 1.

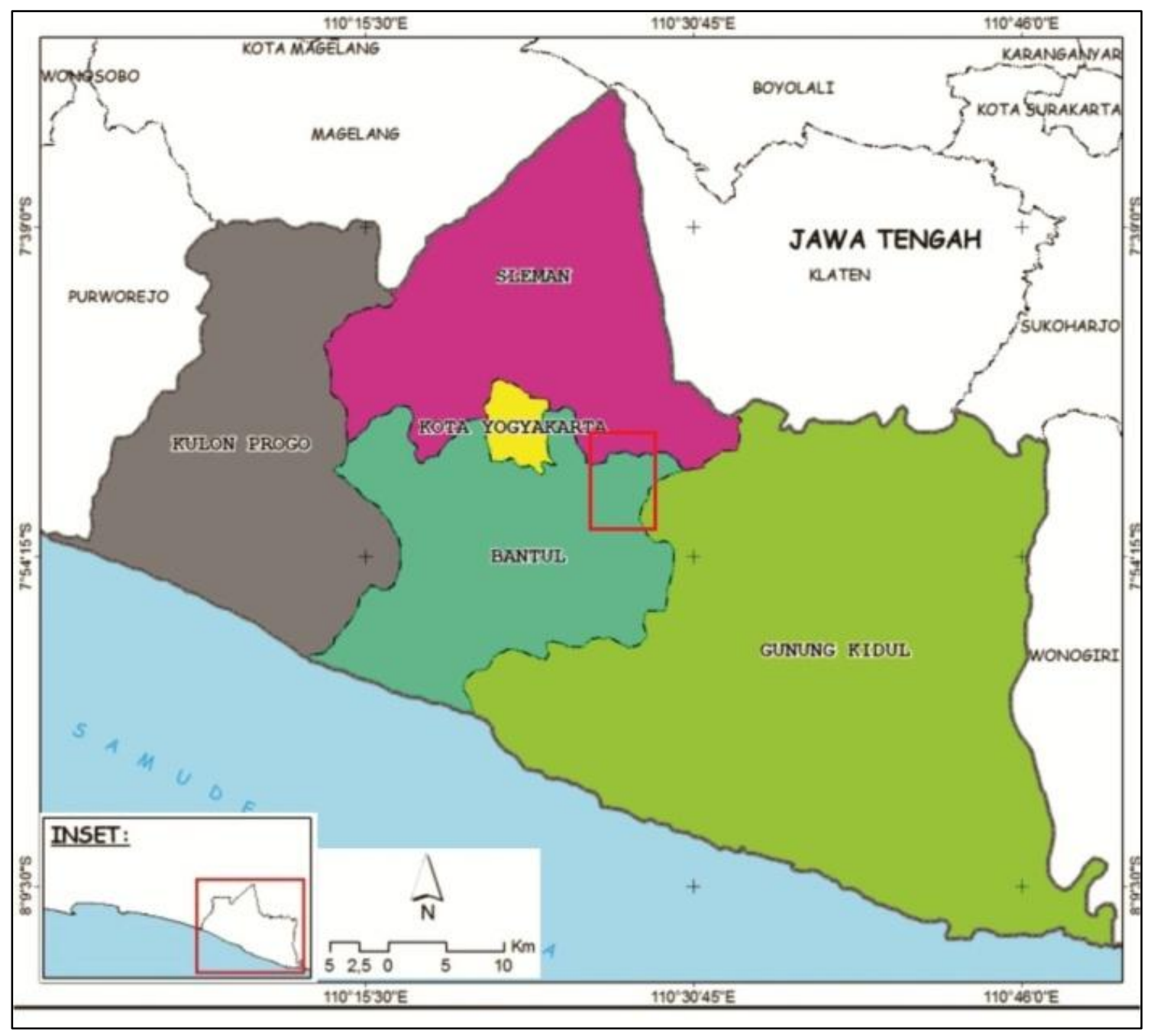

Gambar 1. Lokasi daerah penelitian. 


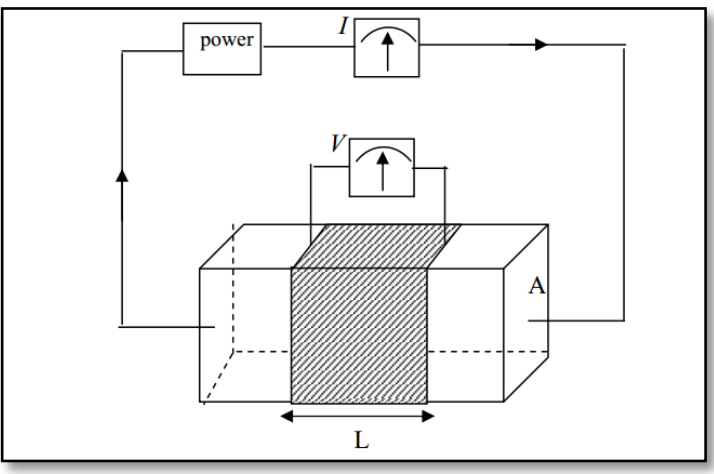

Gambar 2. Contoh batuan yang dilalui arus ${ }^{[4]}$.

Kajian sebaran mineral mangan dalam breksi di daerah Srati, Kebumen dengan menggunakan metode geolistrik Induksi Polarisasi yang terindikasi mempunyai nilai tahanan jenis relatif kecil $(<30 \Omega \mathrm{m})$ sedangkan breksi relatif besar ${ }^{[5]}$. Sedangkan kajian keberadaan akuifer airtanah di daerah batuan gunung api dengan menggunakan metode geolistrik di daerah Nganjuk menunjukkan nilai tahanan jenis dari batuan gunung api cenderung tinggi, namun bila mengandung airtanah memiliki nilai tahanan jenis yang kecil ${ }^{[6]}$.

Secara umum metode resistivitas dapat dibagi menjadi dua, yaitu metode mapping dan sounding ${ }^{[3]}$. Metode mapping digunakan untuk mengetahui variasi resistivitas ke arah lateral. Dalam penelitian ini digunakan pengukuran geolistrik secara mapping dengan menggunakan konfigurasi dipole-dipole (Gambar 3).

Tabel 1. Kisaran harga tahanan jenis batuan dan mineral ${ }^{[4]}$.

\begin{tabular}{|c|c|c|}
\hline Jenis batuan/bijih & $\% \mathrm{H}^{2} \mathrm{O}$ & $\rho$ (ohm-meter) \\
\hline Granit porfiri & & $4,5 \times 10^{3}$ (basah) $-1,3 \times 10^{6}$ (kering) \\
\hline Diorit porfiri & & $1,9 \times 10^{3}$ (basah) $-2,8 \times 10^{4}$ (kering) \\
\hline Granit & $\begin{array}{c}0,31 \\
0,19 \\
0\end{array}$ & $\begin{array}{l}4,4 \times 10^{3} \\
1,8 \times 10^{6} \\
10^{10}\end{array}$ \\
\hline Andesit & & $1,7 \times 10^{2}$ (basah) $-4,5 \times 10^{4}$ (kering) \\
\hline Tuf & & $2 \times 10^{3}$ (basah) $-10^{5}$ (kering) \\
\hline Basal & & $10-1,3 \times 10^{7}$ (kering) \\
\hline Lava & & $10^{2}-5 \times 10^{4}$ \\
\hline Batupasir & $\begin{array}{c}0 \\
1,0\end{array}$ & $\begin{array}{l}1-6,4 \times 10^{8} 4,2 \\
\times 10^{3}\end{array}$ \\
\hline Pirit & & 300 \\
\hline FeAsS & & $10^{-4}-10^{-2}$ \\
\hline $\mathrm{Cu}^{\mathrm{s}} \mathrm{FeS}_{4}$ & & $3 \times 10^{-3}$ \\
\hline $\mathrm{Fe}, \mathrm{Mn}, \mathrm{WO} 4$ & & $10^{3}-10^{7}$ \\
\hline $\mathrm{PbS}$ & & 0,8 \\
\hline $\mathrm{Fe}_{2} \mathrm{O}_{3}$ & & $0,1-300$ \\
\hline $\mathrm{MoS}_{2}$ & & $2 \times 10^{2}-4 \times 10^{3}$ \\
\hline $\mathrm{Cu}_{2} \mathrm{~S}$ & & $3 \times 10^{-2}$ \\
\hline Grapit & & $10^{-4}-5 \times 10^{-3}$ \\
\hline Galena & & 18 \\
\hline Grapit & & $10^{-4}-5 \times 10^{-3}$ \\
\hline Barit & & 8,6 \\
\hline
\end{tabular}




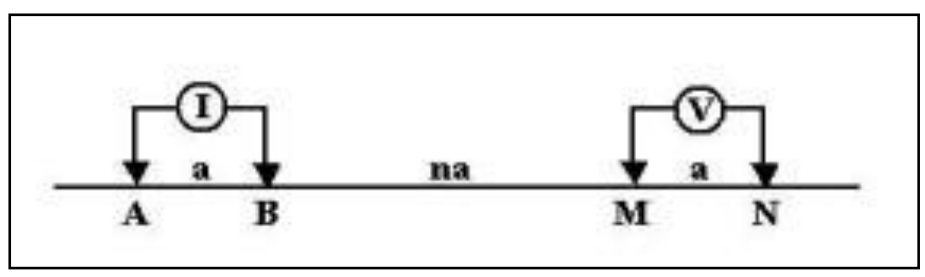

Gambar 3. Susunan elektroda konfigurasi dipole-dipole ${ }^{[3]}$.

Besaran fisis yang diukur langsung di lapangan adalah beda potensial dan kuat arus. Nilai faktor geometri (K) dihitung berdasarkan susunan elektroda yang digunakan. Dengan mensubstitusi faktor K, maka resistivitas (nilai tahanan jenis) batuan dapat diperoleh dari persamaan Hukum $\mathrm{Ohm}^{[4]}$.

$$
\rho=\frac{\Delta V}{I} \cdot K
$$

Besarnya faktor geometri untuk konfigurasi dipole-dipole:

$$
\mathrm{K}=\pi \mathrm{an}(\mathrm{n}+1)(\mathrm{n}+2) \text {. }
$$

sehingga besarnya harga tahanan jenis untuk konfigurasi dipole-dipole adalah

$$
\rho=\frac{\Delta V}{I} \times \operatorname{\pi an}(\mathrm{n}+1)(\mathrm{n}+2) \ldots \ldots
$$

\section{Geologi Umum}

Daerah penelitian merupakan wilayah perbatasan bentang alam antara Pegunungan Selatan di bagian timur dengan Dataran Yogyakarta di sebelah barat. Bentang alam di daerah ini berupa bukit-bukit terisolir (isolated hills) di antara dataran endapan aluvium Gunung api Merapi. Peneliti terdahulu menyebutnya sebagai bukit-bukit inlier karena tersusun atas batuan tua yang dikelilingi oleh endapan muda dan berpendapat bahwa bukit-bukit terisolir tersebut disebabkan oleh kegiatan tektonika berupa pensesaran ${ }^{[1]}$. Hartono dan Bronto menyatakan bahwa bukit-bukit terisolir yang tersusun oleh lava dan atau breksi piroklastika/aglomerat tersebut adalah gunung api purba monogenesis atau mengarah ke komposit dengan sesar mempengaruhi migrasi magma menuju ke permukaan bumi ${ }^{[2]}$.

Secara regional, sebagian besar batuan gunung api Tersier di daerah penelitian termasuk dalam Formasi Nglanggran ${ }^{[7,8]}$. Pembahasan stratigrafi regional daerah penelitian ditekankan pada stratigrafi Pegunungan Selatan Jawa Tengah-Daerah Istimewa Yogyakarta bagian timur, yaitu jalur Baturagung dan Kambengan. Peta geologi Pacitan memaparkan batuan beku intrusi di daerah Pegunungan Selatan terletak di lokasi yang sama atau berdekatan dengan batuan gunung api endapan turbidit ${ }^{[7,8,9]}$. Daerah jalur Baturagung tersusun oleh batuan gunung api berumur Miosen Bawah (Tabel 2).

\section{Gunung Api dan Gunung Api Purba}

Gunung api merupakantempat atau lubang tepat batuan pijar dan atau gas, biasanya kedua-duanya, keluar ke permukaan bumi dan bahan padat yang menumpuk di sekitar bukaan tersebut membentuk bukit atau gunung ${ }^{[10]}$. Tempat atau bukaan tersebut adalah kawah atau kaldera, sedang batuan pijar dan gas adalah magma. Volkanisme adalah proses alam yang berhubungan dengan kegiatan kegunungapian, dimulai dari asalusul pembentukan magma di dalam bumi hingga kemunculannya di permukaan bumi dalam berbagai bentuk dan kegiatannya ${ }^{[10]}$. 
Tabel 2. Kolom stratigrafi Pegunungan Selatan Jalur Baturagung ${ }^{[7,8,9]}$.

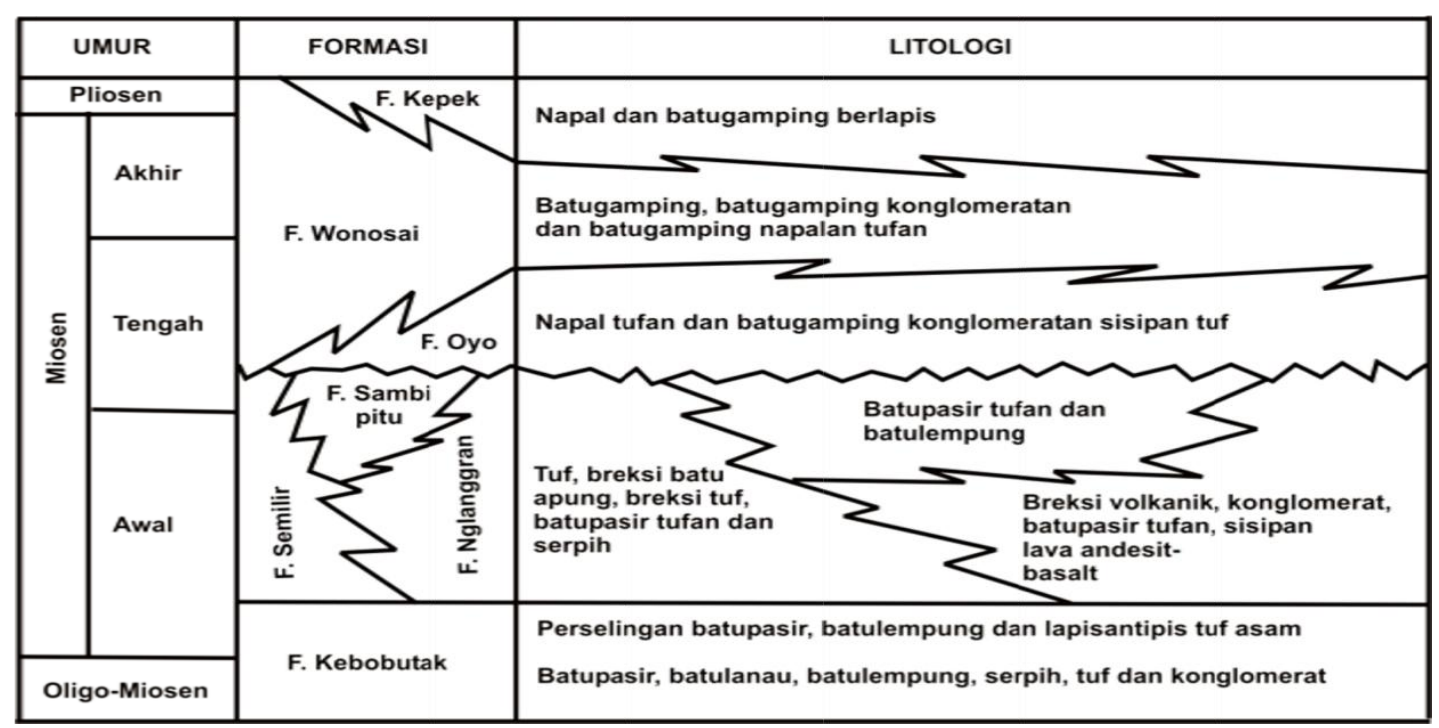

Menurut Bronto gunung api purba atau fosil gunung api (paleovolcanos) adalah gunung api yang pernah aktif pada masa lampau tetapi sekarang ini sudah mati dan bahkan sudah terkisis sangat lanjut sehingga fitur atau penampakan fisis tubuhnya sudah tidak sejelas gunung api aktif masa kini. Bahkan, sebagian sisa tubuhnya sudah ditutupi oleh batuan yang lebih muda. Gunung api purba pada umumnya berumur Tersier (> 2 juta tahun yang lalu) atau lebih tua $^{[11]}$.

Mengingat proses eksogenik yang berjalan sudah sangat intensif sehingga mengakibatkan bentuk kerucut dari gunung api tersebut tidak bisa diamati lagi maka diperlukan pengenalan secara lebih cermat dari gunung api purba tersebut. Pengenalan gunung api purba dapat dilakukan dengan beberapa cara, yaitu melalui pendekatan indraja dan geomorfologi, analisis peta geologi, stratigrafi dan litofasies gunung api, sedimentologi, struktur geologi, petrologi dan geokimia, data pemboran, serta pendekatan analisis geofisika ${ }^{[11]}$.

Studi bentang alam dipakai sebagai indikator awal pemisahan satuan-satuan volcanic terrain dengan mempertimbangkan kondisi morfologi (pola kontur) yang menunjukkan kesamaan resistensi batuan. Pola kontur yang terisolasi menunjukkan suatu tubuh yang lebih resisten dibanding daerah sekelilingnya (intrusi/volcanic neck), sedangkan pola kontur yang menyebar ke suatu arah menunjukkan satuan batuan dan arah akumulasi bahan gunung api. Analisis citra landsat memberikan berbagai penampakan seperti struktur cekungan melingkar (circular depressions), tonjolan setempat, dan lain-lain yang didasarkan pada bentuk atau relief, rona atau warna dan lokasi atau satuan bentang alam. Pusat erupsi adalah bagian paling tinggi dari seluruh daerah yang ditandai oleh pola kontur yang memusat, aliran sungai berpola radier menjauhi sumber erupsi, dan bentuk-bentuk volcanic terrain yang lain.

Pegunungan Selatan Jawa Tengah bagian barat diinterpretsikan adanya bentukan sirkuler (hasil analisis SRTM dan data geomorfologi) yang menunjukkan adanya aktivitas gunung api purba pada umur Tersier. Diantara bentukan sirkuler tersebut dapat dikelompokkan menjadi dua, yaitu kelompok 
gunung api purba Parangtritis-Dengkeng dan Selatan, khususnya yang ada di daerah kelompok gunung api purba Candisari- Berbah-Imogiri seperti yang terdapat pada Nglanggeran (Gambar 4) ${ }^{[12]}$. Kelompok fosil Tabel 3, yang didasarkan pada pengamatan gunung api purba yang ada di Pegunungan singkapan di permukaan ${ }^{[11]}$.

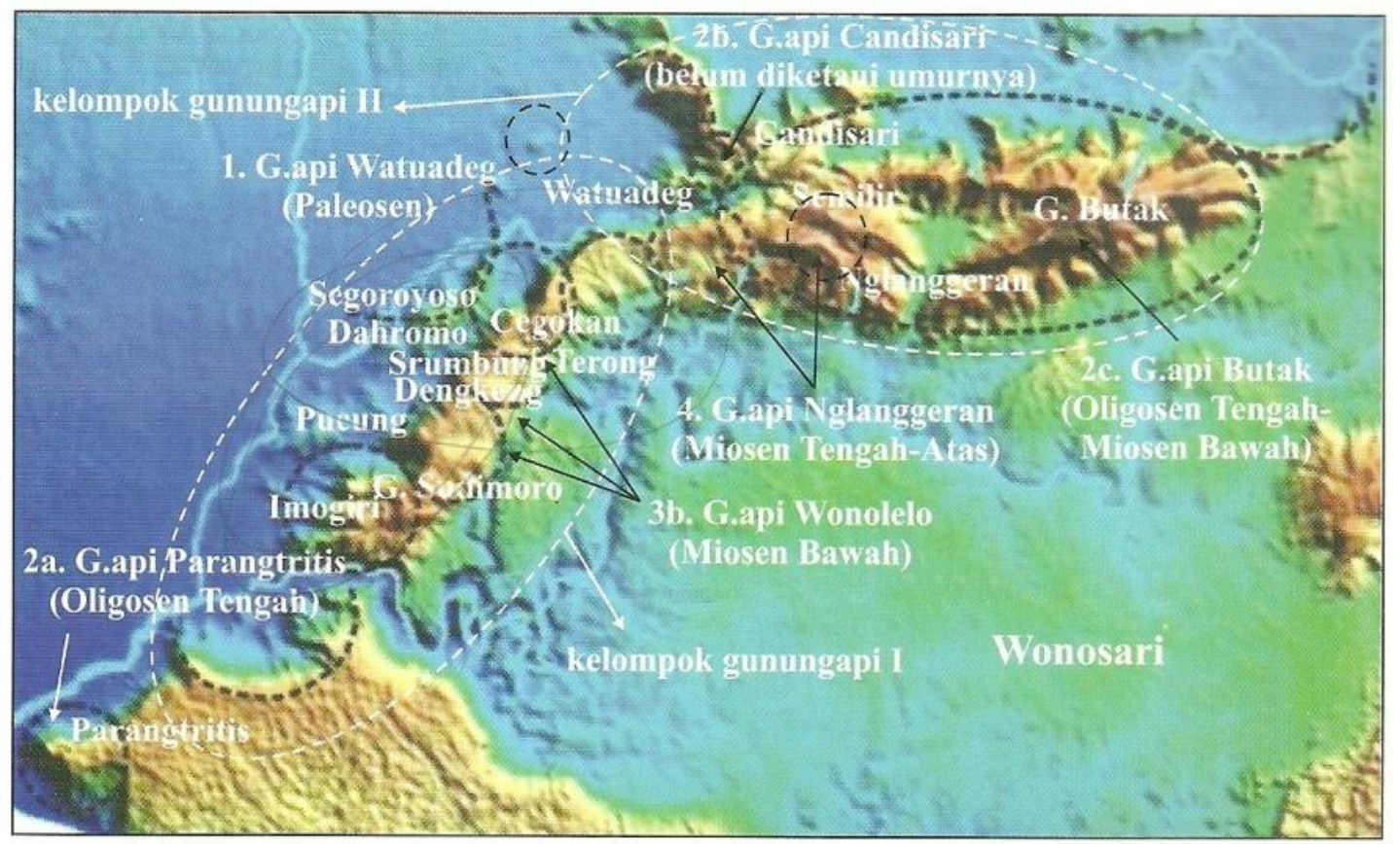

Gambar 4. Interpretasi dua kelompok tubuh gunung api purba di Pegunungan Selatan bagian barat berdasarkan data geomorfologi $^{[12]}$.

Tabel 3. Daftar fosil gunung api purba di Pegunungan Selatan khusunya di wilayah Kabupaten Sleman, Daerah Istimewa Yogyakarta $^{[11]}$.

\begin{tabular}{|c|c|c|c|}
\hline No & $\begin{array}{l}\text { Nama Gunung } \\
\text { Api Purba }\end{array}$ & Lokasi & Indikasi Bentang Alam dan Litologi \\
\hline 1 & G. Wonolelo & $\begin{array}{l}\text { Dusun Guyangan, Desa } \\
\text { Wonolelo, Kecamatan Pleret }\end{array}$ & $\begin{array}{l}\text { Bukit }+123 \mathrm{~m} \text { tersusun oleh perlapisan lava dan } \\
\text { breksi andesit, sisipan konglomerat dan tuf }\end{array}$ \\
\hline 2 & G. Gelap & $\begin{array}{l}\text { Desa Bawuran, Kecamatan } \\
\text { Pleret }\end{array}$ & $\begin{array}{l}\text { Bukit }+131 \mathrm{~m} \text {, tersusun oleh lava dan breksi piro- } \\
\text { klastika basal-andesit basal }\end{array}$ \\
\hline 3 & G. Banyakan & $\begin{array}{l}\text { Dusun Banyakan, Desa } \\
\text { Srimulyo, Kecamatan Piyungan }\end{array}$ & $\begin{array}{l}\text { Bukit }+96 \mathrm{~m} \text {, tersusun oleh lava dan breksi piro- } \\
\text { klastika basal-andesit basal }\end{array}$ \\
\hline 4 & G. Pilang & $\begin{array}{l}\text { Dusun Pilang, Desa Srimulyo, } \\
\text { Piyungan }\end{array}$ & $\begin{array}{l}\text { Bukit }+136 \mathrm{~m} \text {, tersusun oleh breksi piroklastika, } \\
\text { batulapili scoria, tuf dan klastika lava basal- } \\
\text { andesit basal }\end{array}$ \\
\hline 5 & G. Watuadeg & $\begin{array}{l}\text { Dusun Sumberkidul, Desa } \\
\text { Kalitirto, Kecamatan Berbah }\end{array}$ & $\begin{array}{l}\text { Aliran lava basal piroksin berstruktur bantal, } \\
\text { struktur aliran berarah } \mathrm{U} 70^{\circ} \mathrm{T} \text { di bagian utara } \\
\text { sampai dengan } \mathrm{U} 150^{\circ} \mathrm{T} \text { di bagian selatan Kali } \\
\text { Opak, } 200 \mathrm{~m} \text { di sebelah baratnya terdapat bukit } \\
\text { kecil juga tersusun oleh basal piroksen berumur } \\
56,3 \pm 3,8 \mathrm{Ma} \text {. }\end{array}$ \\
\hline
\end{tabular}




\section{Metode}

Metode yang dipergunakan dalam menyelesaikan masalah di atas, yaitu dengan melakukan pengukuran geolistrik resistivitas dengan mapping resistivity, konfigurasi dipole. Pengukuran dilakukan dengan membuat lintasan sebanyak empat buah (Gambar 5) dengan panjang masing-masing lintasan 500 meter. Pengukuran geolistrik resistivitas dimaksudkan untuk mendapatkan harga arus dan potensial dari batuan/mineral.

Dalam melakukan penelitian ini ditunjang oleh beberapa peralatan pendukung (Gambar 6). Peralatan tersebut antara lain resistivitimeter yang dipergunakan untuk mengukur besarnya arus dan beda potensial, sumber arus (genset), kabel multi channel (2 buah) dengan panjang masing-masing 100 meter, kabel mono channel (2 buah) dengan panjang masing-masing 250 meter, elektroda (20 buah), kompas geologi, palu, GPS, tabel data, dan peralatan tulis.

\section{HASIL DAN PEMBAHASAN}

Hasil pemrosesan data geolistrik dari keempat lintasan menghasilkan profil nilai tahanan jenis secara lateral dan horisontal. Keempat profil tersebut tersaji pada Gambar 7-10. Berdasarkan profil tersebut selanjutnya akan diinterpretasikan mengenai jenis litologi, pola peyebaran secara lateral maupun vertikal. Interpretasi didukung oleh data geologi permukaan dan hasil penelitian terdahulu. Setelah dilakukan evaluasi serta interpretasi maka dapat dikelompokkan beberapa jenis batuan yang terdapat di bawah permukaan, kedalaman serta ketebalan yang didapatkan dari nilai tahanan jenis atau resistivitasnya.

\section{Dusun Sumber Kulon, Desa Kalitirto, Kecamatan Berbah, Kabupaten Sleman}

Pengukuran di lokasi ini menghasilkan penampang resistivitas dengan kedalaman 34 meter dari permukaan (Gambar 7) dengan i penampang topografi tinggian di sisi barat laut dan tenggara. Berdasarkan kisaran nilai tahanan jenis dan data singkapan di permukaan maka dapat diinterpretasikan terdapat dua litologi, yaitu lava basal dan tuf dengan sifat yang berbeda.

Pola dengan warna biru muda yang mempunyai nilai resistivitas $17-52,8 \Omega \mathrm{m}$ diinterpretasikan sebagai lava basal yang lapuk dalam keadaan basah dengan pola penyebaran secara setempat-setempat di bagian barat laut sampai ke tengah, dengan kedalaman yang bervariasi antara 3,42-17,4 m. Pola dengan warna hijau muda-orange yang mempunyai nilai resistivitas 52,8-1557 $\Omega \mathrm{m}$ diinterpretasikan sebagai lava basal yang lapuk akan tetapi dalam keadaan kering, dengan penyebaran menerus dari bentangan titik 0-380 m, dan mempunyai kedalaman antara 20 sampai $30 \mathrm{~m}$.

Pola dengan warna merah-ungu yang mempunyai nilai resistivitas $1557 \Omega \mathrm{m}$ sampai >4891 $\Omega \mathrm{m}$ dinterpretasikan sebagai lava basal yang masih dalam keadaan segar, dengan penyebaran dari berada di bawah dari lava basal yang lapuk, berada di antara meter 160 sampai 360 dan kedalamannya >34 meter. Pola dengan warna biru tua-biru muda yang mempunyai nilai resistivitas $1,77-17$ $\Omega \mathrm{m}$ diinterpretasikan sebagai batuan piroklastika berupa breksi pumis, batu lapilli, dan tuf. Secara umum penyebaran batuan berada pada bentangan titik 310-500 m (pada kedalaman mulai dari permukaan sampai $>34$ meter) dan sedikit dijumpai di titik $260 \mathrm{~m}$ yang bersifat mengisi diantara lava basal yang lapuk (pada kedalaman mulai permukaan sampai 17 meter). 


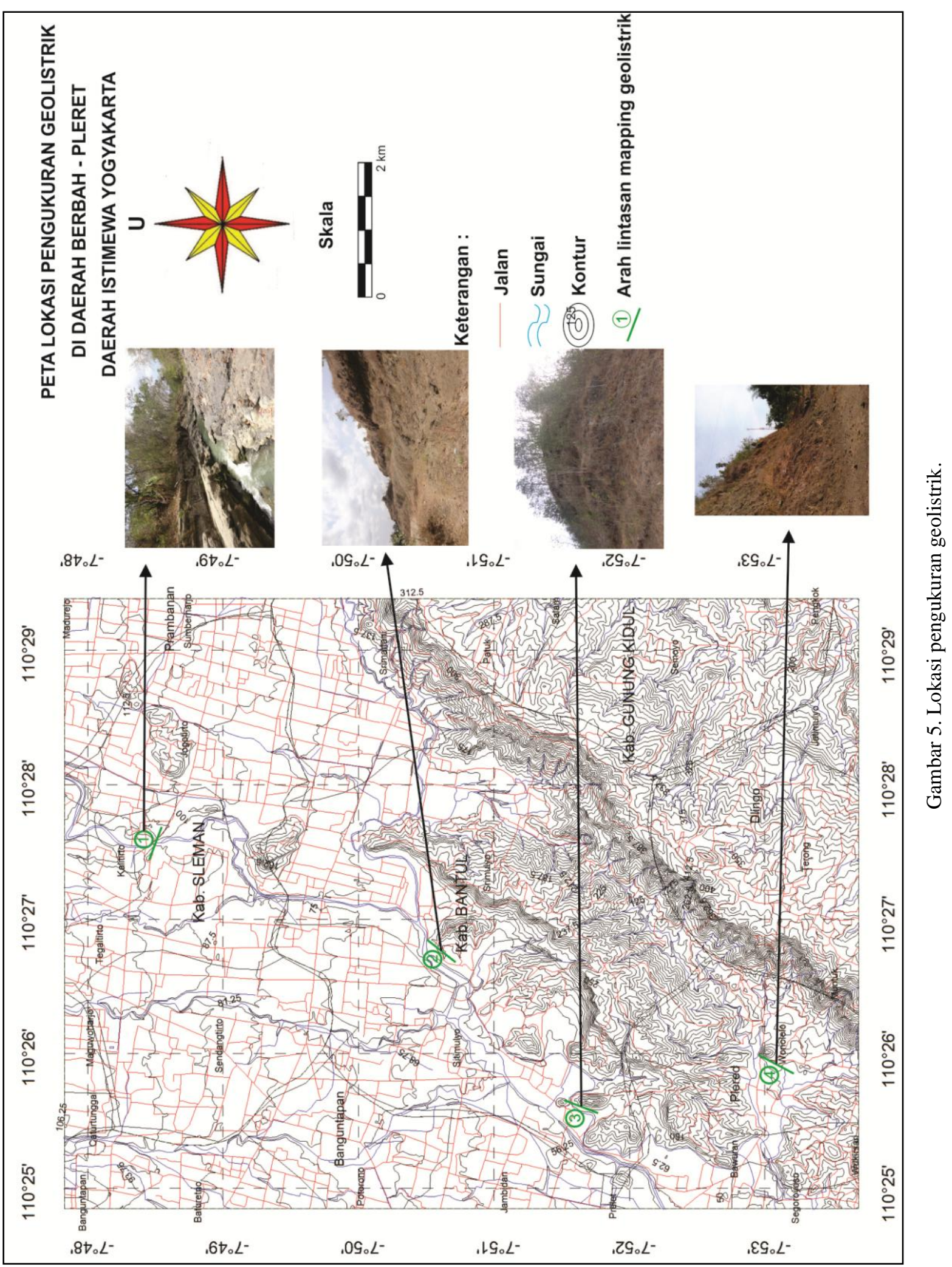


(a)

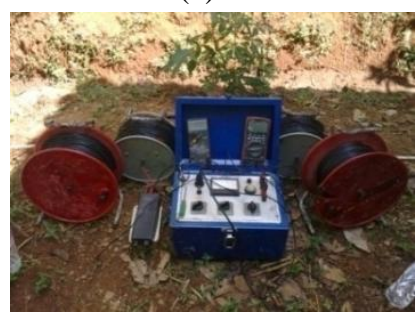

(b)

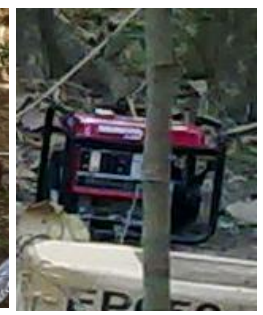

(c)

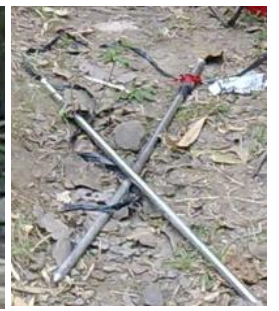

(d)

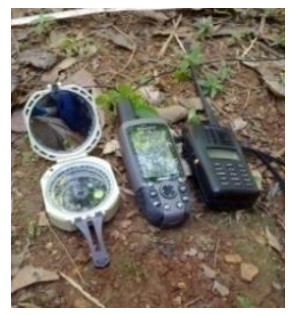

(e)

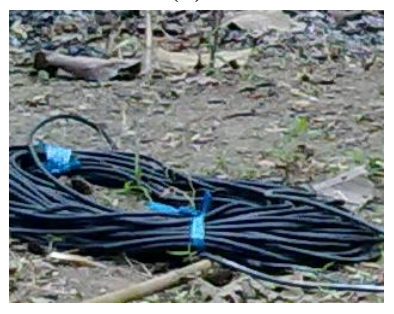

Gambar 6. Peralatan lapangan yang dipergunakan untuk penelitian: a) resistivitimeter, b) sumber arus, c) elektroda, d) kompas geologi, GPS dan HT, e) kabel multi channel.

\section{Dusun Pilang, Desa Srimulyo, Kecamatan Piyungan, Kabupaten Bantul}

Pengukuran geolistrik di lokasi dihasilkan penampang resistivitas dengan kedalaman 34 meter dari permukaan (Gambar 8). Pada penampang terlihat adanya topografi yang relatif datar. Berdasarkan kisaran nilai tahanan jenis dan data singkapan di permukaan maka dapat diinterpretasikan terdapat satu litologi, yaitu breksi skoria yang mempunyai sifat yang berbeda-beda.

Pola dengan warna hijau muda-ungu memiliki nilai resistivitas 5,47-64,5 $\Omega \mathrm{m}$ diinterpretasikan sebagai batuan piroklastika yang lapuk, yaitu breksi skoria basal. Breksi di sini sangat memungkinkan dalam keadaan kompak sehingga tidak terisi air. Pola penyebaran dari batuan ini mulai dari bentangan titik $500 \mathrm{~m}$ dengan kedalaman mulai dari permukaan sampai kedalaman 34 m.

Pola dengan warna biru tua-biru muda memiliki nilai resistivitas $0,86-2,95 \Omega \mathrm{m}$. Kondisi ini diinterpretasikan sebagai material breksi skoria yang banyak mengalami mineralisasi. Kenampakan di lapangan pada breksi skoria ini banyak terisi oleh urat-urat kuarsa yang sangat memungkinkan terisi oleh mineral sekunder. Pola penyebaran dari breksi ini dijumpai secara setempat-setempat pada kedalaman yang bervariasi, yaitu pada kedalaman 17,4 m, 25,3 m, dan $34 \mathrm{~m}$.

\section{Dusun Ngeblak, Desa Bawuran, Kecamatan Pleret, Kabupaten Bantul \\ Penampang resistivitas pada lokasi ini} (Gambar 9) mencapai kedalaman 34 meter dari permukaan. Pada lintasan ini terlihat adanya topografi tinggian di bagian timur laut. Berdasarkan kisaran nilai tahanan jenis dan data singkapan di permukaan maka dapat diinterpretasikan terdapat dua litologi, yaitu tuf dan lava yang mempunyai sifat yang berbeda-beda.

Pola dengan warna biru muda-hijau muda yang mempunyai nilai resistivitas 0,601-32 $\Omega \mathrm{m}$ diinterpretasikan sebagai tuf dengan kondisi lapuk yang bisa terisi air sehingga menurunkan nilai tahanan jenis. Pola penyebaran dari tuf lapuk ini secara lateral mulai dari bentangan titik 30-470 m, serta secara vertikal mulai permukaan sampai kedalaman $34 \mathrm{~m}$.

Pola dengan warna kuning-oranye yang mempunyai nilai resistivitas $132-389 \Omega \mathrm{m}$ diinterpretasikan sebagai tuf dengan kondisi segar dengan penyebaran secara vertikal berada di bawah tuf lapuk pada kedalaman 17,4-34 m, tersebar di bagian tengah sampai barat daya. Pola dengan warna oranye-ungu yang mempunyai nilai resistivitas lebih dari $389 \Omega \mathrm{m}$ dinterpretasikan sebagai lava dengan kondisi segar, dengan pola penyebaran secara vertikal berada di bawah tuf lapuk pada kedalaman 30-34 m. 


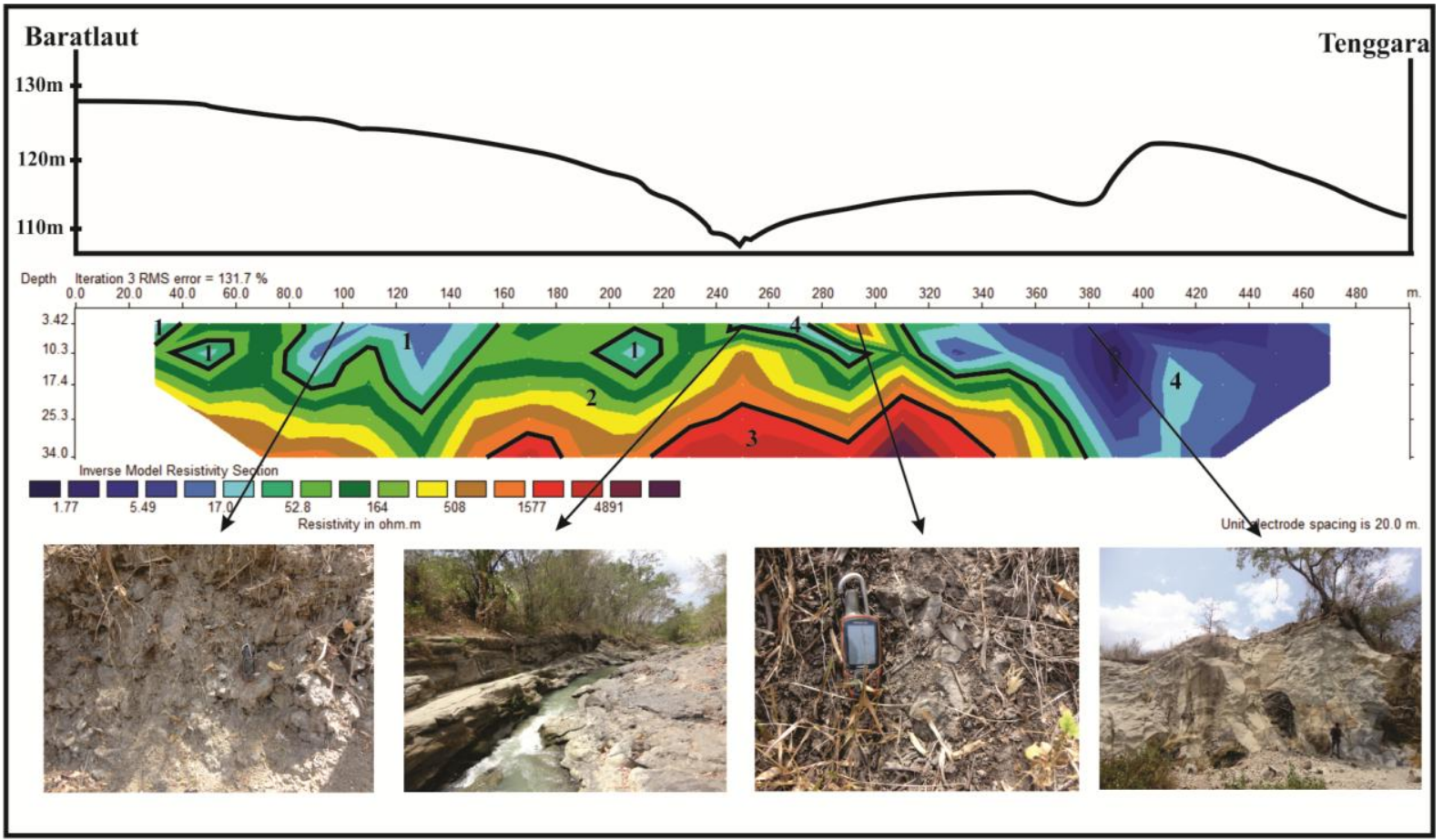

Gambar 7. Penampang geolistrik lintasan 1, Dusun Sumber Kulon, Desa Kalitirto, Kecamatan Berbah, Kabupaten Sleman.

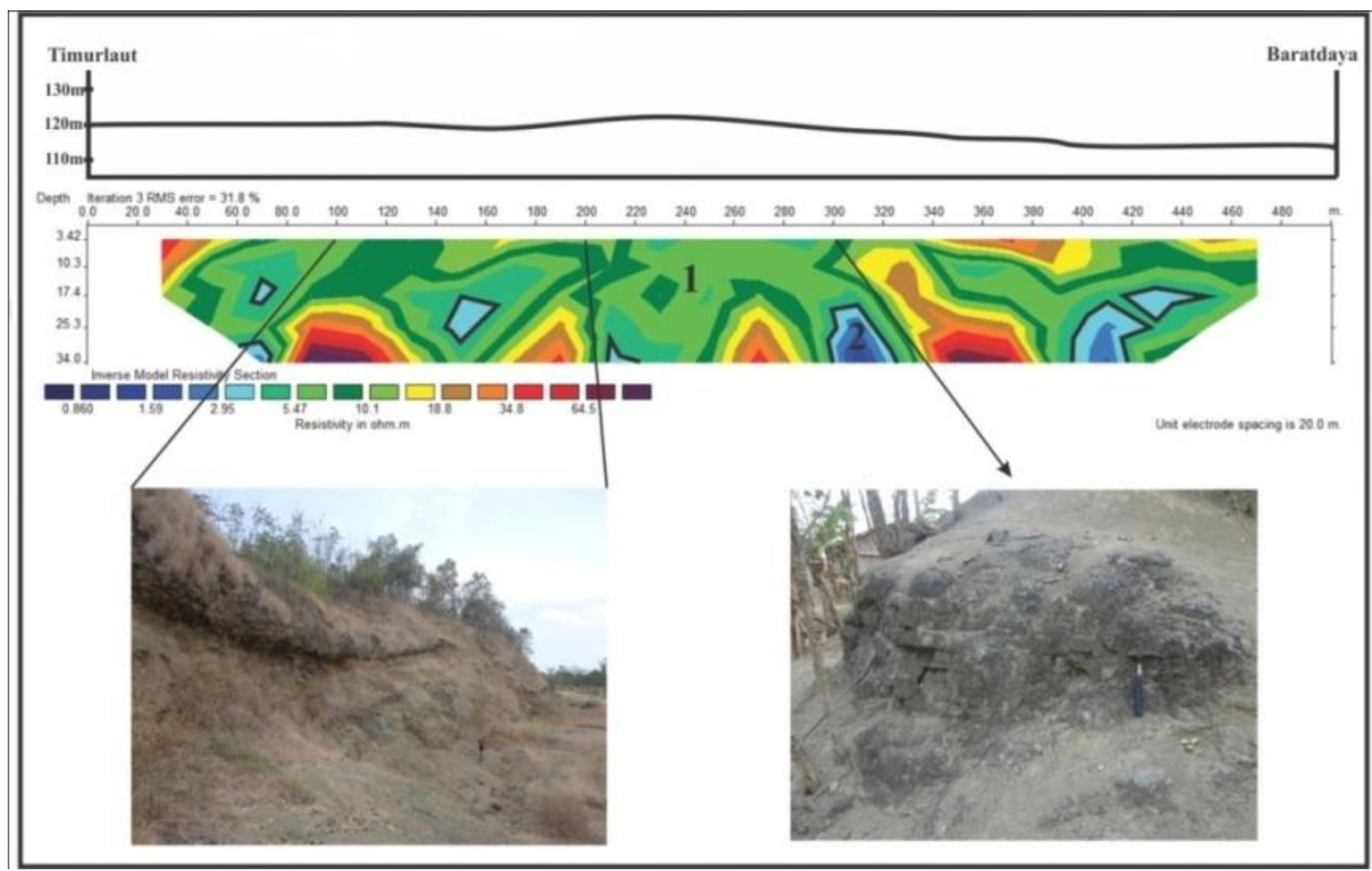

Gambar 8. Penampang geolistrik lintasan 2, Dusun Pilang, Desa Srimulyo, Kecamatan Piyungan, Kabupaten Bantul. 


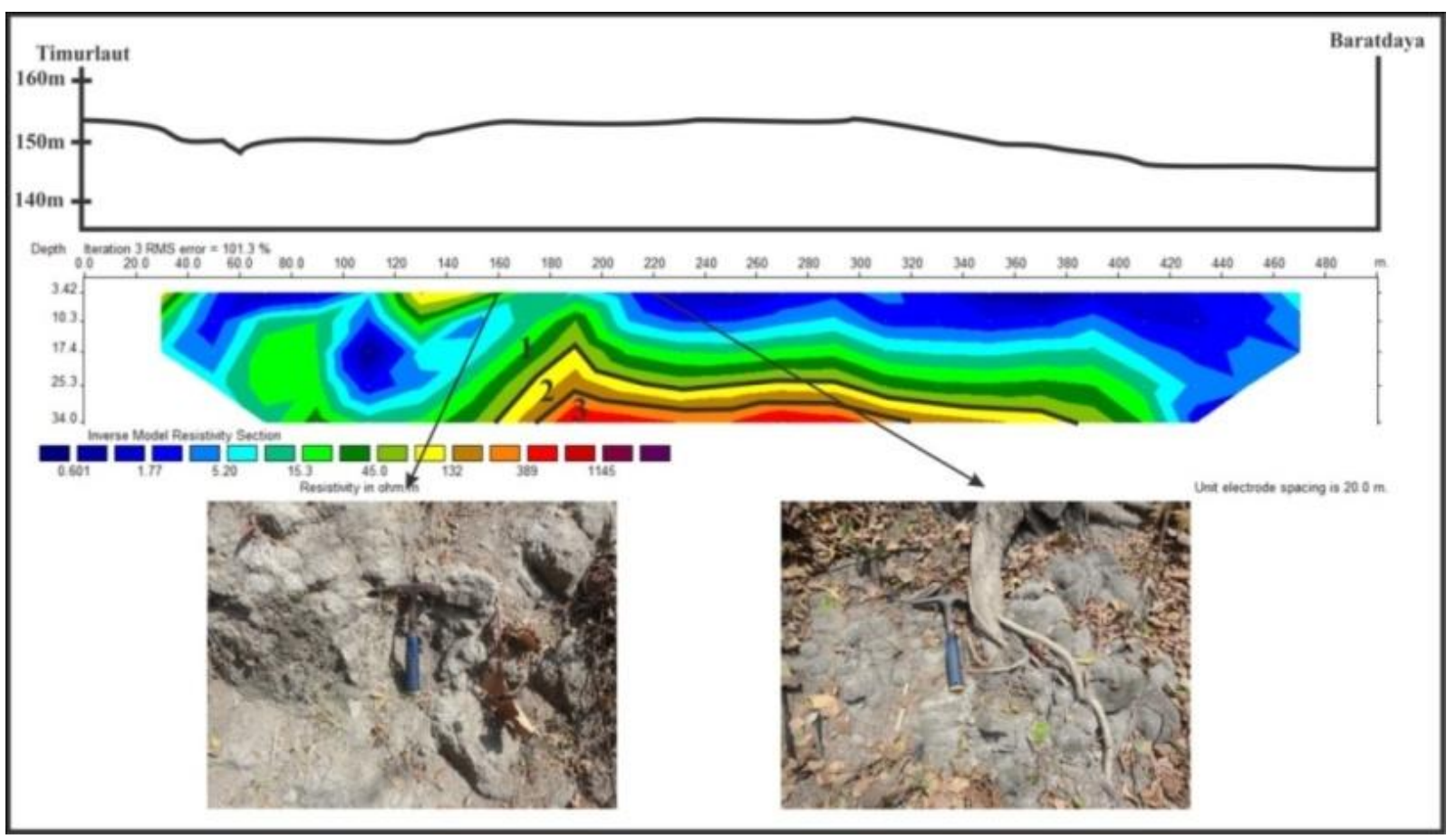

Gambar 9. Penampang geolistrik lintasan 3, Dusun Ngeblak, Desa Bawuran, Kecamatan Pleret, Kabupaten Bantul.

Dusun Guyangan, Desa Wonolelo, Kecamatan Pleret, Kabupaten Bantul

Penampang resistivitas di lintasan ini (Gambar 10) mencapai kedalaman 34 meter dari permukaan. Pada lintasan ini terlihat adanya topografi tinggian di bagian tengah. Berdasarkan kisaran nilai tahanan jenis dan data singkapan di permukaan maka dapat diinterpretasikan terdapat dua litologi, yaitu tuf dan lava yang mempunyai sifat yang berbeda-beda.

Pola dengan warna biru muda-hijau muda yang mempunyai nilai resistivitas $1,39-$ $90 \Omega \mathrm{m}$ diinterpretasikan sebagai tuf dengan kondisi lapuk yang kemungkinan besar banyak mengandung air. Penyebaran secara lateral mulai dari bentangan titik 30-470 m serta secara vertikal mulai permukaan sampai kedalaman $25 \mathrm{~m}$.

Pola dengan warna kuning-oranye yang mempunyai nilai resistivitas 90-364 $\Omega \mathrm{m}$ diinterpretasikan sebagai lava dengan kondisi lapuk. Lava ini dimungkinkan terisi oleh air. Pola penyebaran lava ini secara vertikal berada di bawah tuf lapuk pada kedalaman 0 $34 \mathrm{~m}$ dan hanya dijumpai di bagian tengah sampai timur laut.

Pola dengan warna merah-ungu yang mempunyai nilai resistivitas lebih dari 364 $\Omega \mathrm{m}$ dinterpretasikan sebagai lava dengan kondisi segar. Pola penyebarannya secara vertikal berada di bawah lava lapuk pada kedalaman $>30$ meter. 


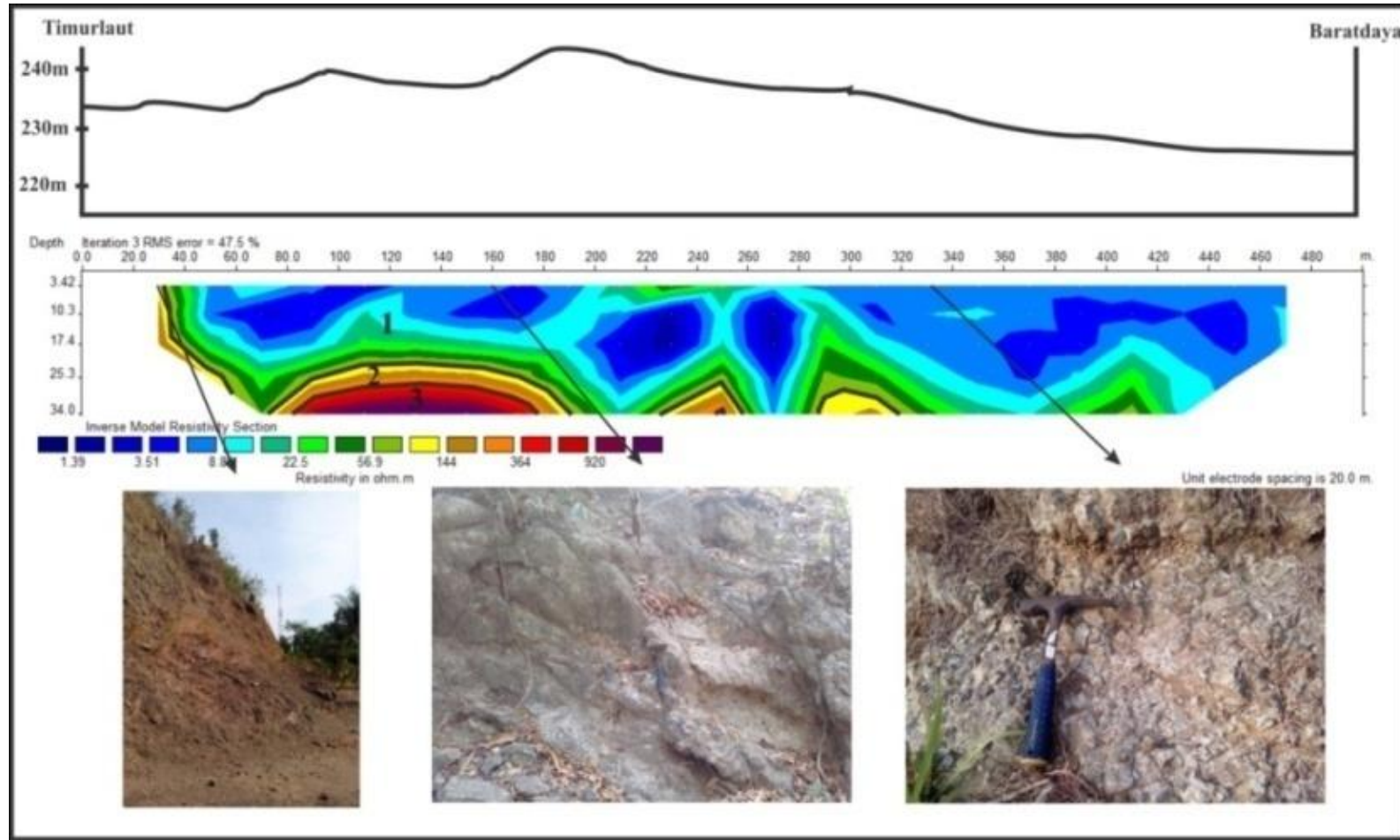

Gambar 10. Penampang geolistrik lintasan 4, Dusun Guyangan, Desa Wonolelo, Kecamatan Pleret, Kabupaten Bantul.

\section{KESIMPULAN}

Daerah penelitian secara fisiografi berada di perbatasan antara Dataran Yogyakarta dengan Zona Pegunungan Selatan bagian barat dan secara regional termasuk dalam Formasi Nglanggran. Hasil penelitian hasil analisis bawah permukaan berdasarkan data geolistrik diinterpretasikan keterdapatan batuan gunung api dengan bentukan morfologi di lapangan menunjukkan adanya isolated hills.

Lokasi pengukuran geolistrik dilakukan secara maping menggunakan konfigurasi dipole-dipole di empat lokasi yang terindikasi sebagai daerah bekas gunung api purba. Lintasan 1 terindikasi adanya batuan gunung api berupa lava basal dan tuf. Lintasan 2 terindikasi batuan gunung api berupa breksi skoria. Lintasan 3 terindikasi adanya tuf dan lava sebagai batuan gunung api dan di lintasan 4 terindikasi batuan gunung api berupa tuf dan lava.

\section{DAFTAR PUSTAKA}

1. ASTUTI, B.S., RAHARDJO, W., LISTYANI, R.A., DAN HUSEIN, S., "Morfogenesa bukit-bukit inlier antara Watuadeg hingga Pengklik, Daerah Berbah, Sleman Yogyakarta”, Prosiding Workshop Geologi Pegunungan Selatan 2007, Badan Geologi, Pusat Survei Geologi, Bandung, 2009.

2. HARTONO, G., \& BRONTO,S., "Lapangan Gunung Api Tersier Daerah Berbah Sleman - Imogiri Bantul, Yogyakarta", Proceedings International Conference on Earth Science and Technology, 1, UGM, Yogyakarta, 2009.

3. DOBRIN, M.B. AND SAVIT, C.H., "Introducton to Geophysical Prospecting", $4^{\text {th }}$ Edition, Mc Graw Hill Co, New York, San Fransisco, 1988.

4. TELFORD, W.M., GELDART, L.P. AND SHERIFF, R.E., “Applied Geophysics" Second Edition, Cambridge 
University Press, Melbourne, Australia, 1990.

5. WINARTI DAN CHUSNI ANSORI, "Studi Induced Polarization (IP) Untuk Eksplorasi Mineral Mangan Di Daerah Strati, Kecamatan Ayah, Kabupetan Kebumen, Jawa Tengah", Prosiding Seminar Nasional Ke-4 RETI, STTNAS Yogyakarta, 2009.

6. WINARTI DAN JOKO SUNGKONO, "Studi Geolistrik Untuk Mengetahui Akuifer Airtanah di Desa Bajulan, Kecamatan Loceret Kabupaten Nganjuk", Seminar Nasional SNTEKPAN, ITAT Surabaya, 2013.

7. RAHARDJO, W., SUKANDARRUMIDI DAN ROSIDI, H.M.D., "Peta Geologi Lembar Yogyakarta, skala 1:100.000”, Direktorat P3G, Bandung, 1977.

8. SURONO, TOHA, B., DAN SUDARNO, I., "Peta Geologi Lembar Surakarta Giritontro, Jawa, skala 1:100.000", Direktorat P3G, Bandung, 1992.

9. SAMODRA, H., GAFOER, S., DAN TJOKROSAPOETRO, S., "Peta Geologi Lembar Pacitan, skala 1:100.000", Direktorat P3G, Bandung, 1992.

10. MACDONALD, A.G., "Volcanoes", Prentice-Hall, Inc. Englewood Cliffs, New Jersey, 1972.

11. BRONTO, S.,"Penelitian Gunungapi Tersier Dan Implikasinya Terhadap Bahan Tambang", dipresentasikan pada Kolokium dan Pameran Pertambangan, Dirjen. Pertambangan Umum, Dep. Pertambangan dan Energi, Bandung, 1997.

12. MULYANINGSIH, S dan SANYOTO, S., "Geologi Gunung Api Merapi; Sebagai Acuan Dalam Interpretasi Gunung Api Komposit Tersiser di
Daerah Gunung Gede-Imogiri Daerah Istimewa Yogyakarta”, Prosiding Seminar Aplikasi Sains \& Teknologi (SNAST) Periode III, Yogyakarta, 2012. 